\title{
The Potential of Food Security Crops in Ethiopia:Review
}

\author{
Zigale Semahegn Yitayeh \\ Ethiopian Institute of Agricultural Research \\ Melkassa Agricultural Research Center, Ethiopia
}

\begin{abstract}
Potential crops are the most important to overcome food insecurity in Ethiopia. This paper also reviews the increasing productivity and production of potential crops through improved technology play great role to achieve food security in Ethiopia. Besides the possible increasing productivity and production of potential or major crops for food security in Ethiopia, through improving productivity of the crop, tackle climate change, tolerance/resistance to major abiotic and biotic factors. In Ethiopia, cereal crops have large coverage both in area and production. Even though out of the total grain crop area, $79.88 \%$ is under cereals and their production is contributed $86.68 \%$ of the grain production while Pulses covered $13.24 \%$ of the grain crop area and their production is $10.38 \%$ of the grain production. These potential crops are mainly the primary component in the most Ethiopians' diet, and also the key to food security in the country. The possible opportunities for increasing major crop production and productivity in Ethiopia are wide suitable land resources, broad crop genetic diversities, availability of different types water resources and conducive government policy. However, challenges also occur in our country like climate change, technological problem, socio-cultural problems, biotic and abiotic factors, lack of skilled manpower, increasing human population growth and they put more people under malnutrition. The major areas of focus on the future major food security crops improvement are improving the productivity of the crop, tackling climate change, capacitating human skill, lowering the total population growth rate through creating awareness on human contraceptive mechanisms, developing tolerance/resistance crops to major abiotic and biotic factors.
\end{abstract}

Keywords: Potential, Production, Food security

DOI: $10.7176 /$ JNSR12-2-02

Publication date: January $31^{\text {st }} 2021$

\section{INTRODUCTION}

Food security is one of the major challenge in the developing countries. The prevalence of food security problem in regions with increasing population growth and more exposed to climate change makes the challenge rather complex and put more people under malnutrition (Parry et al., 1999; Brown et al., 2008; Godfray et al., 2010; Beddington, 2010). Recent data showed that close to 0.8 billion people in the World are undernourished. Around $28 \%$ of these are living in sub-Saharan Africa and of which more than half are living in East Africa (FAO, 2015). Ethiopia is one of the fastest growing economies in the world, with an average annual growth in GDP of 10\% (Paul et al., 2016). Yet, the largest share of the GDP of the country (46.9\%) still comes from agriculture (Diao et al., 2010). Eighty four percent of the country's population lives in rural areas, and a rapid increasing population (expected to double by 2050), slow productivity growth, most of agriculture is under rainfed condition in Ethiopia engaged by small farm management form (Araya et al., 2010), climate-related disasters like droughts increase food insecurity in the rural population. Consequently, competition for available land, water, energy, and other inputs increases, posing pressure on the rural population's livelihoods and food security (Bryan et al., 2009; Garnett et al., 2013). Besides, owing to the poor knowledge about agricultural water requirement, irrigation efficiency is low and crops are under water stress (Valipour, 2012). For centuries, the principal cereals - teff, maize, sorghum and wheat, have fed peasant farmers and their communities in Ethiopia (Se et al., 2012; Yumbya et al., 2014). These major staple cereals are the foremost constituent in the most Ethiopians' diet, and the key to food security in the country. Therefore, the objective of this review was to review the potential of food security Crops in Ethiopia.

\section{LITERATURE REVIEW}

\subsection{Origion, Distribution and Production of major food crops}

Maize originated in Central America and was introduced to West Africa in the early 1500s by the Portuguese traders (Dowswell et al., 1996). It was introduced to Ethiopia during the 1600s to 1700 (Haffangel, 1961). Today, maize is one of the most important food crops world-wide. It has the highest average yield per hectare and is third after wheat and rice in area and total production in the world. It is grown in most parts of the world over a wide range of environmental conditions, ranging between $50^{\circ}$ latitude north and south of the equator. It also grows from sea level to over 3000 meters above sea level (Dowswell et al., 1996). In Ethiopia, maize grows from moisture stress areas to high rainfall areas and from lowlands to the highlands (Kebede et al., 1993). In the 1980s, the total production within a year remained below 20 million quintals and maize production area exceeded slightly 1 million 
hectare only in 1987, 1988 and 1989 (Kebede et al., 1993). However, in the 1990s, maize production in Ethiopia increased: the total area and production remained over 1.3 million hectare and 23.4 million quintals from 19962000 , respectively. The yield per hectare also increased slightly in the late 1990s. From 1995-2000, growth rate per year for yield per hectare, maize area and total production was 3.1\%, $7.1 \%$ and $11.3 \%$, respectively. Jayne et al. (2010)has confirmed rapid growth in wheat consumption as a consequence of urbanization, rising incomes, and dietary diversification in Eastern and Southern Africa. While many countries in Africa are largely dependent on wheat imports to meet their growing demands, Ethiopia is one country where smallholder wheat production is prominent, allowing it to meet more than $70 \%$ of the demand from domestic production (Shiferaw et al., 2011). These statistics indicate the critical importance of improving the productivity and production of wheat through generation and development of improved wheat technologies in order to promote broad-based economic growth and poverty reduction in Ethiopia. Both bread wheat and durum wheat are grown in Ethiopia and about $87 \%$ is grown during the main growing season (meher). While bread wheat is a recent introduction to Ethiopia, durum wheat is indigenous and mainly grown in the Central and Northern highlands.

One of the key strategies pursued by the government for ensuring food security in the country was to expand the availability of modern wheat varieties for farmers. In 2009/10 main season, the total area under wheat production was 1.68 million ha while the total production was about 3.07 million tons (CSA, 2011). Over the same time period, wheat accounted for about $16 \%$ of the total area of cereals in Ethiopia. There are about 4.6 million farm households (36\% of cereal farm households) who are directly dependent on wheat farming in Ethiopia. The national average productivity of wheat is 1.83 tons/ha (CSA, 2011). Despite the low yields, demand for wheat has been growing fast in both rural and urban areas in the country. Changes in dietary patterns and a rapid growth in wheat consumption have been noted over the past few decades in several countries in sub-Saharan Africa (SSA) (Morris and Byerlee, 1993; Shiferaw et al., 2011).

Few and scattered reports have been published on the early history of teff. (Vavilov, 1957) recorded Ethiopia as the center of origin for teff. According to Rouk and Hailu Mengesha (1963), the Biochemistry Department of Oklahoma State University reported 10 to $11 \%$ protein, 2 to $3 \%$ fat, about $81 \%$ nitrogen free extract; and about $0.2 \%$ calcium and $0.4 \%$ phosphorus from moisture free basis analysis of teff seeds.( Di Maio et al. 1962) stated that the balance among the essential amino acids was excellent in teff, except for lysine. Chichaibelu (1965) showed experimentally that it was possible to improve the teff diet by supplementing with fenugreek ( Trigonella foenum-graecumn) and L-Lysine

Sorghum has been found as an indigenous crop to Ethiopia with enormous genetic diversity. According to CSA (2012), sorghum stands $3^{\text {rd }}$ next to tef and maize in area and second in total production next to maize. It is predominantly cultivated in dry lowlands that cover nearly $66 \%$ of the total area of the country (Geremew et al., 2004). It covers $16 \%$ of the total area allocated to grains and $20 \%$ of the area covered by cereals. Currently, there are about 5,166,690 holders with area coverage of 1,923,717 ha and production of 39,512,942 quintals of grain.

\subsection{Crop research}

The availability of improved maize technologies (improved varieties and management practices) for different agroecologies combined with new extension program played a major role in the increment of maize production in the 1990s. On the half hectare demonstration plots of Sasakawa Global 2000 (SG-2000) and the similar government extension program, hybrids gave an average yield of 50-60 q/ha in potential areas. This represents a $250 \%$ increment over the average yield obtained by traditional practices in the country (Benti et al., 1997). Chiovenda wrote, in 1912, about Ethiopian wheats and reported T. dicoccum, T. durum, T. polonicum and T. vulgare types (Central Statistics Office (CSO). 1987). Later, Percival in 1927 (IS), Vavilov in 1929 and 1932 ( Vavilov, N.I. 1929, Vavilov, N.I. 1932) and Ciferri and Giglioli in 1939 (Chiovenda, E. 1912, Ciferri, R., and G.R. Giglioli. 1939a, Ciferri, R., and G.R. Giglioli. 1939b ) undertook expeditions and reported on Ethiopian wheat germplasm.

A formal wheat improvement program started in 1949 at the Paradiso Government Station near Asmara with the testing of large numbers of indigenous and exotic varieties. As a result, some promising local variety selections, including AlO, R18, P20 and H23, and 3 bread wheat varieties of Kenyan origin, namely Kenya 1, 5 and 6, were released during the early 1950s. Scientific research on tef began in the late 1950s, and over the years a number of improved varieties (about 30 at the national level) and management practices have been developed. However, the research outputs were so little adopted by the farmers and have brought few discernible impacts. Being of local importance, no international funding or research attention was given to it until recently. For tef, outstanding support has been provided by the McKnight Foundation's Collaborative Crop Research Program (MF-CCRP) to the Ethiopian Institute of Agricultural Research since 1996.

\subsection{Overview of potential crops in Ethiopia}

Crop Production Survey indicate that a total land area of about 12,486,270.87 hectares are covered by grain crops i.e. cereals, pulses and oilseeds, from which a total volume of about 266,828,807.04 quintals of grains are obtained, from private peasant holdings (CSA, 2015/2016) (TABLE 1). Out of the total grain crop area, 79.88\% 
$(9,974,316.28$ hectares) was under cereals. Teff, maize, sorghum and wheat took up22.95\% (about 2,866,052.99 hectares), 16.91\% (about 2,111,518.23 hectares), $14.85 \%$ (about 1,854,710.93 hectares) and 13.33\% (about $1,664,564.62$ hectares) of the grain crop area, respectively(CSA, 2015/2016). Cereals contributed 86.68\% (about $231,287,970.83$ quintals) of the grain production. Maize, teff, wheat and sorghum made up $26.80 \%(71,508,354.11$ quintals), $16.76 \%(44,713,786.91$ quintals $), 15.81 \%(42,192,572.23$ quintals $)$ and $16.20 \%(43,232,997.52$ quintals $)$ of the grain production(CSA, 2015/2016), in the same order. Pulses grown in 2015/16 (2008 E.C.) covered $13.24 \%$ $(1,652,844.19$ hectares) of the grain crop area and 10.38 (about 27,692,743.11 quintals) of the grain production was drawn from the same crops. Faba beans, chick peas, haricot beans (red) and haricot beans (white) were planted to $3.56 \%$ (about 443,966.09 hectares), 2.07\% (about 258,486.29 hectares), 1.95\% (about 244,049.94 hectares) and $0.91 \%$ (about 113,249.95 hectares) of the grain crop area(CSA, 2015/2016). The production obtained from faba beans, chick peas, haricot beans (red), and haricot beans (white) was 3.18\% (about 8,486,545.69 quintals), $1.77 \%$ (about 4,726,113.88 quintals), $1.43 \%(3,804,994.53$ quintals) and $0.60 \%(1,597,394.84$ quintals) of the grain production, in that order(CSA, 2015/2016). Oil seeds added $6.88 \%$ (about 859,110.39 hectares) of the grain crop area and $2.94 \%$ (about 7,848,093.10 quintals) of the production to the national grain total. Sesame, Neug and linseed covered 3.11\% (about 388,245.50 hectares), 2.25\% (about 281,036.36 hectares) and 0.68\% (about $85,415.67$ hectares) of the grain crop area and 1.03\% (about 2,742,174.27 quintals), $0.96 \%$ (about 2,563,271.66 quintals) and $0.33 \%$ (about 885,511.44 quintals) of the grain production, respectively(CSA, 2015/2016).

Table. 1 Total area in Hectares and Total production in Quintals

\begin{tabular}{|l|l|l|l|l|}
\hline \multirow{2}{*}{ Crop Category } & \multicolumn{2}{c|}{ Total Area In } & \multicolumn{2}{c|}{ Total Production In } \\
\cline { 2 - 5 } & Hectares & \multicolumn{1}{c|}{$\%$} & Quintals & $\%$ \\
\hline Cereals & $9,974,316.28$ & 79.88 & $231,287,970.83$ & 86.68 \\
\hline Pulses & $1,652,844.19$ & 13.24 & $27,692,743.11$ & 10.38 \\
\hline Oil Seeds & $859,110.39$ & 6.88 & $7,848,093.10$ & 2.94 \\
\hline Grain Crops & $12,486,270.87$ & 100.00 & $266,828,807.04$ & 100.00 \\
\hline
\end{tabular}

Source:CSA 2015/2016

\subsection{Opportunities}

\subsubsection{Land resources}

The total area of the country is said to be about 1.17 million $\mathrm{km} 2$ or 117 million hectares, over $60 \%$ of which can be used for some form of agricultural production activities. However, according to CSA's annual survey of land under crops by small-scale farmers over many years show that it has been in the range of 13-14 million hectares in any given year (FDRE/CSA 2013/14-a). The overwhelming proportion (95\%) of the cropped area is under small-scale rain-fed farming that accounts for $95 \%$ of the national annual crop production.

\subsubsection{Bio-diversity (Genetic) resources}

Ethiopia is recognized as one of the eight Vavilovian centers of origin or genetic diversity for many economically important crops (Huff nagel, 1961). Even some of the non-indigenous crops and livestock introduced into the country so long ago that they have adapted to the local environmental conditions so well that they act as indigenous species. The greatest majority of farmers and herders rely on these species of crops and livestock in agricultural production activities.

\subsubsection{Water resources}

Many rivers flow out of the country because of its high altitude that forces such outf lows to the surrounding countries. In addition to the relatively high rainfall, particularly in the western part, the country is endowed with a significant amount of water resources from lakes and rivers as well as from under-ground sources. It is estimated that the country's irrigation potential is close to 5.4 million hectares, comprising of over 3.7 million hectares from surface water sources (rivers and lakes), over 1.16 million hectares from ground water sources and about 0.5 million hectares from rain water harvesti ng (Sileshi Bekele Awulachew, 2010) .

\subsection{Challenges}

\subsubsection{Climate change}

Climate change involves long-term changes in mean temperature and/or rainfall patterns and increased climate variability, reflected by an increasing occurrence of severe climate events such as droughts and floods (Smit and Skinner, 2002; IPCC, 2007). Poor, mainly subsistence-based and natural resource-dependent societies in developing countries are especially vulnerable to climate change. They are sensitive and exposed to natural hazards, and the severity and higher frequency of such hazards undermines the asset portfolio needed to adequately cope and to adjust to them (Ribot et al., 2009; UNDP, 2007). For the millions of small farmers in developing countries already struggling to eke out vulnerable livelihoods, one dire consequence is an increase in food insecurity. This is a particular risk in regions where climate acts both as an underlying chronic issue and a short-lived shock, as poor farmers often have a low ability to cope with shocks and to mitigate long-term stresses (Bohle et al., 1994; Dilley and Boudreau 2001; Gregory et al., 2005; Challinor et al., 2007). Although it is also true that they have 
impressive and widely documented coping abilities, these are expected to be challenged by the scope and speed of future climate change (Challinor et al., 2007). Household-level food insecurity is due to seven main drivers: those that act by reducing food production (poverty, lack of education, unavailability of employment, failures in property rights), those that act by restricting access to food (food price increases), and those that act via both channels (poor market access and climate/environmental change) (Scholes and Biggs, 2004). In contexts where these drivers play a key role, such as Sub-Saharan Africa, climate change will further stress already vulnerable livelihoods, making it difficult to reach the United Nations Millennium Development Goals adopted in 2000, especially with regard to halving the proportion of people who suffer from hunger by 2015 (Rosegrant and Cline, 2003). Hence, development agencies need to facilitate the adaptation of agricultural systems by improving the adaptability of food systems in the face of climate change. This will decrease the vulnerabilities of the poor and enhance their food security (Mortimer and Adams, 2001; Smit and Skinner 2002; Howden et al., 2007; Lobell et al., 2009). This also implies investing in adaptive processes that secure food availability (production, distribution and exchange) as well as food access (affordability, allocation and preference) and food utilization (nutritional and societal values and safety).

The largest investments in food production continue to be associated with agricultural innovations, which are often advocated as crucial for agricultural climate change adaptation (e.g., Ainsworth et al., 2008). These initiatives, predominantly breeding programs to increase the productivity of some major crops and livestock, are increasingly in the hands of fewer private biotechnology and agribusiness actors (Byerlee and Fisher, 2002). Much less emphasis is being put on local systems that rely on existing natural, human and social assets such as biodiversity, traditional knowledge and social capital underpinning collective action to ensure food security (Thrupp, 2000; Esquinas-Alcázar, 2005; Scherr and McNeely, 2008; Jackson et al., 2010; Brussard et al., 2010). Ethiopia's agriculture is overwhelmingly rainfall-dependent, it suffers greatly from the risks associated with high rainfall variability. Longterm records indicate that there have been severe and repeated rainfall failures resulting in severe food/feed insecurity, including famines, on the Ethiopian population due to signifi cant loss of crops and livestock. The frequency and severity of these natural shocks has increased in recent years (Mahoo et al., 2013). Needless to say, such shocks result not only in hardships to human and animal populati ons but also thwart seriously economic development efforts. Moreover, climate change places more pressure on the food security of millions by reducing crop yields, increasing land degradation, and lowering water availability. For example, a bioeconomic analysis using maize crop as a case study indicate that the number of food insecure people in Ethiopia would increase by up to 2.4 million by 2050 as a result of the impact of climate change not only on production but also on global agricultural import and export trade and prices (Tesfaye et al., 2014).

\subsubsection{Technological problem}

The Ethiopian farming and herding communiti es have been, and sti 11 are, largely dependent on traditi onal crop "land races", indigenous animal stocks as well as poor management practi ces and poorly organized value chains, parti cularly marketi ng systems. This state of aff airs results not only in low crop and animal producti vity but also in inadequate incenti ves to encourage greater producti on and producti vity. Although "modern" agricultural educati on, research and extension have been introduced to the country since the mid-1930s (during the Italian occupation)(Huff nagel, 1961), the generation, transfer and adopti on of improved agricultural technologies and practi ces is sti 11 far less than required to meet the producti on needs of food, feed and industrial raw material of the country. Despite the best eff orts of the nati onal agricultural research, extension and marketi ng insti tuti ons, adopti on of improved crop varieti es, modern agricultural inputs (seeds, ferti lizers, crop protecti on chemicals, farm machines and implements, etc.) and enhanced value chain systems have yet to make signifi cant inroads into the agricultural communiti es, although there have been some progress made in the last few decades.

\subsubsection{Socio-cultural problems}

Socio-cultural attitudes can be said that the overwhelming majority of the Ethiopian agricultural communities, be they sedentary or nomadic, are highly traditional and prefer to live by traditional values and norms considered appropriate to their respective communities. This is highly affected by the high level of poverty and food insecurity leading to risk aversion by way of being reluctant to adopt new technologies and new ways of doing things. These sets of traditional socio-cultural attitudes make the introduction and adoption of improved agricultural practices that have the potential for adaptation and/or mitigation against natural shocks very difficult and a long-term process. As a result, many decades of effort to promote the adoption of improved crop varieties, animal breeds and agricultural management practices have failed to make significant changes in the Ethiopian agricultural production system. Thus, farmers' responses to natural shocks remain largely traditional and poorly developed to withstand shocks. Another dimension to socio-cultural issues relates to gender streamlining in agricultural activities and in other economic development sectors. It is known that female members of the agricultural communities play a very vital role in many agricultural activities (Lemlem Arega et al., 2011). Many of the technologies generated through agricultural research do not adequately focus on the special requirements of women and girls. It also needs to be added that both the nati onal agricultural extension system as well as the financial institutions also fail to properly address the need to develop mechanisms to minimize, if not eliminate, 
gender-bias in extending their services. Therefore, the huge potential that can be developed by streamlining genderissues has been lost over the years. However, there are current indications that may improve the situation, even at speeds lower than desired.

\section{SUMMARY AND CONCLUSION}

The needed increasing in potential crops productivity and production for food security can be achieved through research (by improving crops) and optimization of crop management practices. However, progress is slow because of lack of basic knowledge on major crops production and lack of trained manpower and infrastructures. As producing the potential crop, the research is carried out in our country by researchers based at higher learning and research institutions. In spite of their prime importance in the Ethiopian agriculture, the major bottlenecks constraining production of major food security crops are low yielding, diseases and pests, climate change, increase population, limited technology and lack of skilled manpower. For centuries, the major crops, especially cereals teff, maize, sorghum and wheat and pulse crops, have fed the Ethiopian farmers and their communities. These staple cereals are mainly the foremost component in the most Ethiopians' diet and also the key to food security in rural Africa. The major areas of focus on the future major food security crops improvement include: improving the productivity of the crop, tackling climate change, advancing human skill, lowering the total population growth rate, developing tolerance/resistance crops to major abiotic and biotic factors.

\section{REFERENCES}

Ainsworth, E.A., Rogers, A., and Leakey, A.D.B. 2008. "Targets for crop biotechnology in a future high-CO2 and high-O3 world". Plant physiology, 147(1): 13-9.

Almgard, Gunnar. 1963. High contenit of iron in teff, Eragrostis abyssinica Link., and some other crop species from Ethiopia a result of contamination. Lantbrukshogskolans Annaler 29: 215-220.

Asfaw Negasa, Abdissa Gemeda, Tesfaye Kumsa and Gemechu Gedeno. 1997. Agro-ecological and socioeconomical circumstances of farmers in East Wollega zone of Oromia. Research report No. 32. IAR, Addis Ababa, Ethiopia.

Beddington, J., 2010. Food Security: Contributions from Science to a new and greener

Benti Tolessa, Kebede Mulatu, Legesse Wolde, Mosisa worku and Leta Tulu. 1997. Reflections on the successful achievements of hybrid maize breeding program in Ethiopia. pp. 67-71. In: Ransom, J.K., A.F.E. Palmer, B.T. Zambezi, Z.O. Muduruma, S.R. Waddington, K.V. Pixley and D.C. Jewell (eds.). Maize Productivity Gains through Research and Technology Dissemination. Proceedings of the Fifth Eastern and Southern Africa Regional Maize Conference, Arusha, Tanzania, June 3-7, 1996, CIMMYT, Addis Ababa, Ethiopia.

Benti Tolessa, Tasew Gobezayehu, Mosisa Worku, Yigzaw Desalegne, Kebede Mulatu and Gezahigne Bogale. 1993. Genetic improvement of maize in Ethiopia: A Review. pp. 13-22. In: Benti Tolessa and J.K. Ransom (eds.). Proceedings of the First National Maize Workshop of Ethiopia. May 5-7, 1992. IAR/CIMMYT, Addis Ababa, Ethiopia.

Berhane Gebrekidan and Bantayehu Gelaw. 1989. The maize mega-environments of Eastern and Southern Africa and germplasm development. pp. 197-211. In: Birhane Gebrekidan (ed). Proceedings of the Third Eastern and Southen Africa Regional Maize Workshop. Nairobi, Sep. 18-22, 1989. CIMMYT, Nairobi, Kenya.

Bohle, H.G., Downing, T.E. and Watts, M.J. 1994. "Climate change and social vulnerability: Toward a sociology and geography of food insecurity". Global Environmental Change,4(1): 37-48.

Brown, M.E., Funk, C.C., 2008. Food Security under Climate Change. Science. 319:580-581.

Brussaard, L., Caron, P., Campbell, B., Lipper, L., Mainka, S., Rabbinge, R., Babin, D. and Pulleman, M. (2010). "Reconciling biodiversity conservation and food security: scientific challenges for a new agriculture". Current Opinion in Environmental Sustainability,2(1-2): 3442.

Bryan, E., Deressa, T.T., Gbetibouo, G.A., Ringler, C., 2009. Adaptation to climate change in

Byerlee, D. and Fischer, K. 2002. "Accessing modern science: policy and institutional options for agricultural biotechnology in developing countries". World Development,30(6): 931-948.

Central Statistics Authority (CSA), 1990-2001. Agricultural sample survey reports on area, production for major crops (private peasant holdings meher season). The FDRE Statistical Bulletins (1990-2001),

Central Statistics Office (CSO), 1987. Agricultural sample survey, 1986/ 87. Addis Ababa: CSO.124138.adaptation to climate change: Evidence from rural Ethiopia. Glob. Environ. Change 36, Addis Ababa, Ethiopia.

Challinor, A., Wheeler, T., Garforth, C., Craufurd, P. and Kassam, A. 2007. "Assessing the Vulnerability of Food Crop Systems in Africa to Climate Change". Climatic Change,83(3): 381-399.

Chichaibelu, Beyene. 1965. Studies on the biological evaluation of the protein quality of teff (Eragrostis abyssinica) and abish (Trigonetla foenum-graecum) and the supplementary value of abish when added to tef. (Unpublished Master's thesis, Cornell University, Ithaca, New York. Ciferri, R., and Isaia Baldrati. 1939. I Cereali dell' Africa Italiana, Col. II. "Teff" (Eragrostis teff). Cereale da panificazione dell' Africa Italiana 
Montana. Firenze, XI. De Maio, L. R. et al.1962. Amino acid composition and Lysine supplementation of teff. J. Agr. Food Chem. 10: 62-64

Chiovenda, E. 1912. Ethiopia: Osservazioni botaniche, agrarie et industriali. Fatte nell' Abissinia settertrionale nell'anno 1909. Roma, Italy.

Ciferri, R., and G.R. Giglioli. 1939a. Cereal cultivation in East Africa (Ethiopia). 1. The hard (durum) wheats. L'Italia Agricola 76: 247-257.

Ciferri, R., and G.R. Giglioli. 1939b. Cereal cultivation in East Africa (Ethiopia). 2. The wheats (Triticum) pyramidale, turgidum, poloniC11111 and dicoccum. L'ltalia Agricola 76: 379-387.

CSA, 2011. Ethiopia Demographic and Health Survey (EDHS), Preliminary Report. Addis Ababa: CSA.

CSA (Central Statistical Agency), 2011. Report on Area and Production of Major Cereals (Private Peasant Holdings, Meher Season). Agricultural Sample Survey 2110/11 (2003 E.C.), Volume 1. Addis Ababa, Ethiopia

CSA, 2015/2016. Federal democratic republic of Ethiopia agricultural sample survey.

Degene Mokonnen and Habtamu Zeleke. 1993. Maize breeding and improvement for the eastern highlands of Ethiopia. pp. 22-24. In: Benti Tolessa and J.K. Ransom (eds.). Proceedings of the First National Workshop of Ethiopia. May 5-7, 1992. IAR/CIMMYT, Addis

Dev. 38, 1375-1383.

Diao, X., Hazell, P., Thurlow, J., 2010. The Role of Agriculture in African Development. World

Dilley, M. and Boudreau, T.E. 2001. "Coming to terms with vulnerability: a critique of the food security definition". Food Policy,26(3): 229-247.

Esquinas-Alcázar, J. 2005. "Protecting crop genetic diversity for food security: political, ethical and technical challenges". Nature Reviews Genetics,6: 946-953.

Ethiopia and South Africa: options and constraints. Environ. Sci. Policy 12, 413-426.

Ethiopia Nutrition Survey. 1959. A report by the Interdepartmental Committee on Nutrition for National Defense. Wasbington, D. C.

FAO, 2015. The state of food security in the World. Food and Agriculture Organization of the

FAO/ WFP,2012. Crop and Food Security Assessment Mission to Ethiopia. Rome/Addis Ababa: FAO/WFP. April 2012.

FAO/WFP [Food and Agriculture Organisation and World Food Programme],2010. State of Food Insecurity in the World. Rome: FAO/WFP.

FDRE/CSA, 2013/14. Agricultural Sample Survey Vol I: Report on Area and Producti on of Major crops (private peasant holdings, Meher Season) Addis Ababa

FDRE/CSA, 2013/14. Agricultural Sample Survey Vol II: Report on Area Livestock and Livestock Charaterisiti cs (private peasant holdings, Meher Season) Addis Abeba

Gilbert, F. A. 1953. Mineral Nutrition of Plants and Animals. University of Oklaboma Press, Norman, Oklahoma. pp. 50-54.

Godfray,H.C.J., Beddington, J.R., Crute, I.R., Haddad, L., Lawrence, D., Muir, J.F., Pretty, J.,

Gregory, P.J., Ingram, J.S.I. and Brklacich, M. (2005). "Climate change and food security". Philosophycal Transaxtions of the Royal Society, B 360: 2139-2148.

Howden, S.M., Soussana, J.S., Tubiello, F.N., Chhetri, N., Dunlop, M. and Meinke, H. (2007). "Adapting agriculture to climate change". PNAS, 104(50): 19691-19696.

Huff nagel, H.F., 1961. Agriculture in Ethiopia. FAO, Rome

IPCC, 2007. "Summary for Policymakers". In Parry, M.L., Canziani, O.F., Palutikof, J.P., Van der Linden, P.J. and Hanson, C.E. (Eds.): Climate Change 2007: Impacts, adaptation and vulnerability. Contribution of Working Group II to the Fourth Assessment Report of the Intergovernmental Panel on Climate Change. Cambridge University Press, Cambridge, UK: 7-22.

Jackson, L., van Noordwijk, M., Bengtsson, J., Foster, W., Lipper, L., Pulleman, M., Said, M., Snaddon, J. and Vodouhe, R. 2010. "Biodiversity and agricultural sustainagility: from assessment to adaptive management". Current Opinion in Environmental Sustainability,2(1-2): 80-87.

Jayne, T.S., Mason, N., Myers, R., Ferris, J., Mather, D., Beaver, M., Lenski, N., Chapoto, A., Boughton. D., 2010. Patterns and trends in food staples markets in eastern

Koernicke, F., and H. Werner. 1885. Handbuch des Getreidbaues. Vol. I and II. Paul Pares, Berlin, Germany.

Lobell, D.B., Burke, M.B., Tebaldi, C., Mastrandrea, M.D., Falcon, W.P. and Naylor, R.L. 2008. "Prioritizing climate change adaptation needs for food security in 2030". Science, 319(5863): 607-610.

Marvin Miracle, Maize in Tropical Africa (Madison, 1966).

Mekasha, A., Tesfaye, K. and. Duncan, A. J 2014a. Trends in daily observed temperature and precipitation extremes over three Ethiopian ecoenvironments. International Journal of Climatology 34: 1990-1999 Mahoo H., Radney M., Kinyanji J., and Cramer L., eds., 2013. Climate Change Variability and Risk Assessment of Agriculture and Food Security in Ethiopia: Which Way Forward? CCAFS Working Paper N0. 
59. CGIAR Research Program on Climate Change, Agriculture and Food Security (CCAFS). Copenhagen, Denmark.

MoFED [Ministry of Finance and Economic Development], 2010. The Federal Democratic Republic of Ethiopia: Growth and Transformation Plan (2010-2014/15), Draft Document: Addis Ababa

Morris, M.L., Byerlee, D., 1993. Narrowing the wheat gap in Sub-Saharan Africa: a review of consumption and production. Economic Development and Cultural Change 41 (4), 737-761.

Mortimor, M.J. and Adams, W.M. 2001. "Farmer adaptation, change and 'crisis' in the Sahel". Global Environmental Change, 11: 49-57.

Oerke, E.C. 2006. Crop losses to pests. Journal of Agricultural Science, Vol. 144, pp. 31-43

Parry, M., Rosenzweig, C., Iglesias, A., Fischer, G., Livermore, M. 1999. Climate Change and

Paul, C.J., Weinthal, E.S., Bellemare, M.F., Jeuland, M.A., 2016. Social capital, trust, and revolution. Philos T Roy Soc B.365:61-71.

Ribot, J.C., Najam, A. and Watson, G. 2009. "Climate Variation, Vulnerability and

Robinson, S., Thomas, S.M., Toulmin, C. 2010. Food Security: The Challenge of feeding 9 Billion People. Science. 327:812-818

Rosegrant, M.V. and Cline, S.A. 2003. "Global Food Security: Challenges and Policies". Science,302(5652): 1917-1919.

Rouk, H. and Hailu Mengesha. 1963. An introduction to t'ef. A nutritious cereal grain of Ethiopia. Agr. Exp. Sta. Bul. No. 26. College of Agri., Dire-Dawa, Ethiopia.

Scherr, S.J. and NcNeely, J.A. 2008. "Biodiversity conservation and agricultural sustainability: towards a new paradigm of 'ecoagriculture' landscapes". Phil. Trans. R. Soc. B,363(1491): 477-494.

Scholes, R.J. and Biggs, R. 2004. Ecosystem services in Southern Africa: a regional assessment. Pretoria, South Africa: Council for Scientific and Industrial Research.

Shiferaw, B., Negassa, A., Koo, J., Wood, J., Sonder, K., Braun, J-A., Payne, T., 2011. Future of Wheat Production in Sub-Saharan Africa: Analyses of the Expanding Gap between Supply and Demand and Economic Profitability of Domestic Production. Paper presented at the Agricultural Productivity-Africa Conference 13 November 2011, Africa Hall, UNECA, Addis Ababa, Ethiopia.Wooldridge, J.M., 2002. Econometric Analysis of Cross Section and Pa

Sileshi Bekele Awulachew, 2010. Irrigati on Potenti al in Ethiopia: Constraints and Opportunities for enhancing the System. IWMI, Addis Ababa.

Smit, B. and Skinner, M.W. 2002. "Adaptation options in agriculture to climate change: A typology". Mitigation and Adaptation Strategies for Global Change,7: 85-114.

Sustainable Development in the Semi-arid Tropics". In Shipper, E.L.F. and Burton, I. (Eds.): Adapation to Climate Change. Earthscan, London: 117-160.

Thrupp, L.A. 2000. "Linking agricultural biodiversity and food security: The valuable role of agrobiodiversity for sustainable agriculture". International Affairs,76(2): 283-297.

UNDP, 2007. Fighting Climate change: Human Solidarity in a Divided World. Human development report 2007/2008. Palgrave Macmillan, New York.

UNDP [United Nations Development Programme], 2011. Human Development Report 2011. New York: UNDP. United Nations, Rome.

Vavilov, N. I. 1951. The origin, variation, immunity and breeding of cultivated plants. Translated from the Russian by K. Starr Chester. The Ronald Press Co., New York. pp. 37-38.

Vavilov, N.I. 1929. Wheats of Ethiopia. Bull. Applied Botany, Genetics and Plant Breeding. 20: 324-356.

Vavilov, N.I. 1932. The Abyssinian wheats. 'A contribution to the classification of 28 chromosome wheats. Bull. Applied Botany, Genetics and Plant Breeding Suppl. 51. Leningrad.

World food security: a new assessment.Global Environ Change. S51-S67. 